\title{
Corrosion of Q345B Steel in Soil Solution Extract Containing Chloride Ions
}

\author{
Qian Wang, Linchun Zhang*, Ailian Zhang
}

School of Civil Engineering, Sichuan College of Architectural Technology, Deyang 618000, China; *E-mail:zhanglinchun1980@126.com

Received: 24 October 2021 / Accepted: 19 November 2021 / Published: 5 January 2022

\begin{abstract}
As a common steel structure material, Q345B steel is widely used in outdoor steel structures, but there are few studies on the corrosion of the buried part of Q345B steel in the service process of potential chlorine ion pollution environments. Therefore, the corrosion behavior of Q345B steel in a soil solution contaminated by sodium chloride was investigated by using the open circuit potential, electrochemical impedance spectroscopy, potentiodynamic polarization, energy dispersion spectroscopy, laser scanning confocal microscopy and weight loss method. The results show that the corrosion product films formed by Q345B steel in different soil solutions are mainly composed of $\mathrm{Fe}$ oxide, and the material surface shows the coexistence of overall corrosion and local slight uneven corrosion. In soil contaminated by $\mathrm{NaCl}$, the competitive adsorption of $\mathrm{Cl}^{-}$on the electrode surface of Q345B steel will reduce the selfcorrosion potential of Q345B steel and improve the corrosion current. The solution resistance and charge transfer resistance of the soil leaching solution decreased, the weight loss rate of the materials increased, the number of corrosion active points increased, and the corrosion of Q345B steel was induced from light-colored and pitted corrosion to dark and banded corrosion. However, $\mathrm{Cl}^{-}$had no obvious effect on the formation and development of pitting corrosion of Q345B steel.
\end{abstract}

Keywords: Q345B, steel structure, chlorine, pollution

\section{FULL TEXT}

(C) 2022 The Authors. Published by ESG (www.electrochemsci.org). This article is an open access article distributed under the terms and conditions of the Creative Commons Attribution license (http://creativecommons.org/licenses/by/4.0/). 